\title{
APLIKASI PENCARIAN RUTE PENUGASAN PENGAMBILAN SAMPAH KABUPATEN BLITAR BERBASIS WEBSITE
}

\author{
Afrilia Sriwahuyuni, Hani Zulfia Zahro', Renaldi Primaswara Prasetya \\ Program Studi Teknik Informatika S1, Fakultas Teknologi Industri \\ Institut Teknologi Nasional Malang, Jalan Raya Karanglo km 2 Malang, Indonesia \\ apriliaxwhy@gmail.com
}

\begin{abstract}
ABSTRAK
Lingkungan merupakan tempat berlangsungnya bermacam-macam interaksi sosial. Saat ini kualitas lingkungan terus mengalami penurunan akibat berbagai aktivitas yang dilakukan oleh manusia. Hal inilah yang menjadi faktor utama menurunnya kualitas lingkungan dan sosial masyarakat karena peningkatan jumlah volume sampah yang setiap harinya terus meningkat. Pemerintah daerah untuk saat ini masih mengalami kendala dalam mengalokasikan sampah yang ada di daerah karena keterbatasan TPS dan TPA. Dengan jarak yang jauh antara TPS dan TPA pemerintah harus mengeluarkan dana yang cukup besar setiap harinya. Dengan adanya kendala tersebut perlu adanya rute pangangkutan sampah dari TPS menuju TPA. Penulis bertujuan membuat sistem Informasi Geografis yang memetakan rute penugasan pengambilan sampah pada wilayah Blitar, Jawa Timur. Sehingga dengan adanya Sistem. Pada pengujian yang telah dilakukan hasil pengujian fungsional $100 \%$ berjalan sesuai kebutuhan. Pada pengujian desktop menunjukkan $100 \%$ sesuai dan pengujian pada perankat mobile menunjukkan hasil $100 \%$ dibuktikan dengan tata letak yang telah sesuai.
\end{abstract}

Kata Kunci : Dinas Lingkungan Hidup (DLH), WebGIS, Leaflet, Jawa Timur, SIG

\section{PENDAHULUAN}

Lingkungan merupakan tempat berlangsungnya bermacam-macam interaksi sosial. Saat ini kualitas lingkungan terus mengalami penurunan akibat berbagai aktivitas yang dilakukan oleh manusia. Tuntutan kebutuhan hidup yang terus bertambah membuat semakin meningkatnya pola konsumsi masyarakat tanpa diimbangi dengan sikap peduli terhadap lingkungan. Hal inilah yang menjadi faktor utama menurunnya kualitas lingkungan dan sosial masyarakat karena peningkatan jumlah volume sampah yang setiap harinya terus meningkat. Berdasarkan data pemerintah pada tahun 2019 jumlah produksi sampah di Indonesia mencapai 67 ton dan akan terus mengalami pengingkatan setiap tahunnya. Penanganan sampah yang dilakukan pemerintah yaitu menggunakan metode 3R (Reduce, Reuse, Recycle) karena sampah menjadi sumber daya terbarukan di sektor industri. Namun pemerintah perlu melakukan sosialisasi pada masyarakat tentang kepedulian terhadap sampah dan mencari solusi untuk sampah yang kian meningkat.

Pemerintah daerah untuk saat ini masih mengalami kendala dalam mengalokasikan sampah yang ada di daerah karena keterbatasan TPS dan TPA. Dengan jarak yang jauh antara TPS dan TPA pemerintah harus mengeluarkan dana yang cukup besar setiap harinya. Dengan adanya kendala tersebut perlu adanya rute pangangkutan sampah. Saat ini Dinas Pemerintah daerah (DLH) masih menggunakan cara manual untuk mendata rute penugasan pengambilan sampah. Sehingga perlu adanya solusi dari permasalahan tersebut dengan memanfaatkan tekonologi informasi.
Dengan adanya penelitian mengenai Sistem Infromasi Geografis rute penugasan pengambilan sampah yang menmapilkan titik lokasi TPS dan rute penugsan sopir dump truck pada Dinas Lingkungan Hidup Kabupaten Blitar diharapkan dapat memberikan informasi dan dapat meminimalisir waktu pengangkutan sampah, sehingga kinerja dapat berjalan secara optimal.

\section{TINJAUAN PUSTAKA \\ 2.1 Penelitian Terdahulu}

Pencarian rute terpendek (Shortest path problem) merupakan suatu permasalahn optimasi mencari rute minimum yang diperlukan untuk mencapai tempat tujuan berdasarkan beberapa jalur laternatif yang tersedia [1].

Penelitian penentuan lokasi Tempat Pembuangan Akhir (TPA) yang memenuhi kriteria kesesuaian lokasi berdasarkan SNI dengan menggunakan data Penginderaan Jauh berupa citra Lansdsat dan foto udara. Cakupan citra landsat yang luas digunakan untuk mengidentifikasi lahan yang layak berdasarkan bentuk dan penggunaan lahan. Lokasi potensial diperoleh dari pengharkatan berjenjang yang dilanjutkan dengan penapisan menggunakan peta Rencana Penggunaan Lahan untuk mendapatkan lokasi rekomendasi. Penelitian ini menghasilkan 2 lokasi rekomendasi dengan luasan masing-masing 36,62 ha, dan 32,62 ha [2].

Penelitian membuat aplikasi Sistem Informasi Geografis (SIG) untuk pemetaan sebaran tempat pembuangan sampah ilegal di Kota Banjarbaru. Penelitian ini bertujuan untuk mematakan sebaran tempat pembuangan sampah (TPS) illegal dan menganalisis faktor-faktor yang mempengaruhi. Data penelitian diperoleh melalui pengamatan dan 
pengukuran secara langsung di lapangan serta studi pustaka. Hasil penelitian menunjukkan bahwa di Kota Banjarbaru terdapat 64 lokasi TPS illegal dan sebarannya dipengaruhi oleh jarak dari sungai, jarak dari jalan utama, dan jarak dari jalan local [3].

Penelitian terhadap analisis truk pengangkut sampah di wilayah seberang ulu Kota Palembang. Sistem pengangkutan sampah berhubungan dengan biaya dalam pengelolaannya. Semakin jauh rute pelayanan dan semakin banyak jumlah ritasi truk maka semakin besar pula biaya operasional yang harus dikeluarkan. . Sistem pengangkutan sampah di wilayah Seberang Ulu Kota Palembang menggunakan Hauled Container System (HCS) dan Stationary Container System (SCS). Hasil analisis aktivitas pengangkutan sampah didapatkan waktu rata-rata untuk pengangkutan dalam satu kali ritasi perhari dengan armroll truck adalah 2,88 jam/hari dan jumlah ritasi rata-rata per hari adalah sebanyak 2,28 ritasi/hari dan armroll truck dengan nomor lambung 81 merupakan armroll truck dengan biaya angkut sampah/m3/hari [4].

Penelitian dilakukan untuk membuat model dinamis pengelolaan sampah untuk mengurangi beban penumpukan. Terbatasnya Tempat Pembuangan Akhir (TPA) berbanding terbalik dengan daya beli masyarakat yang semakin tinggi. Dalam penelitian ini dilakukan analisis pengelolaan sampah untuk mengurangi beban penumpukan sampah di TPA dengan menggunakan simulasi berdasarkan pendekatan sistem dinamis. Berdasarkan hasil analisa, baik dengan sistem dinamis maupun dengan Analytic Hierarchy Process (AHP) dan Benefit-Cost ratio (B/C), maka sebaiknya pengelolaan sampah di DKI dilakukan secara bertahap, pertama adalah dengan pengomposan dan kemudian dengan incinerator [5].

\subsection{Dasar Teori}

\subsubsection{Sistem Informasi Geografis}

Sistem Informasi Geografis adalah system berbasisi computer yang memiliki kemampuan dalam menangani data bereferensi geografi yaitu pemasukan data, manajemen data (penyimpanan dan pemanggilan kembali), memanipulasi dan analisis data, serta keluaran sebagai hasil akhir (output) [6].

\subsubsection{WebGis}

Web-GIS merupakan Sistem Informasi Geografi berbasis web yang terdiri dari beberapa komponen yang saling terkait. Web-GIS merupakan gabungan antara design grafis pemetaan, peta digital dengan analisa geografis, pemrograman komputer, dan sebuah database yang saling terhubung menjadi satu bagian web design dan web pemetaan. Dimana sebuah Web-GIS yang potensial merupakan aplikasi GIS yang tidak memerlukan software GIS dan tidak tergantung pada platform ataupun sistem operasi [7].

\subsubsection{Leaflet}

Leaflet adalah Javascript Library terkemuka yang bersifat opensource untuk membangun peta interaktif yang Mobile friendly. Dengan ukuran hanya sekitar $38 \mathrm{~kb}$, memiliki semua fitur pemetaan yang dibutuhkan sebagian besar pengembang [8].

Kelebihan opensource tersebut adalah lebih mudah untuk dikembangkan oleh peneliti selanjutnya dan mudah untuk mengadaptasi dengan teknologi baru pada GIS [9].

Leaflet secara langsung dapat dibandingkan dengan OpenLayers, karena keduanya adalah open source, JavaScript library hanya sisi klien. library secara keseluruhan jauh lebih kecil, sekitar 7.000 baris kode dibandingkan dengan 230.000 OpenLayers per tahun 2015. Namun, Leaflet tidak memiliki fitur yang didukung OpenLayers, seperti Web Feature Service (WFS) dan dukungan asli untuk proyeksi selain Google Web Mercator [10].

\section{METODE PENELITIAN}

Metode penelitan yang diterapkan pada penelitian ini adalah sebagai berikut :

1. Lokasi Penelitian

Penelitian ini dilakukan pada lokasi TPS

yang tersebar pada wilayah Kabupaten Blitar.

2. Sampel Data

a. Data jumlah Tempat Penampungan Sementara (TPS) Kabupaten Blitar

b. Titik koordinat lokasi TPS Kabupaten Blitar

c. Jumlah Kendaraan atau armada pengangkutan sampah

d. Petugas pengangkutan sampah

3. Prosedur penelitian

a. Menentukan rute dengan menggunakan titik koordinat

b. Pengumpulan data pada Dinas Lingkungan Hidup (DLH) Kabupaten Blitar

4. Menggunakan Bahasa pemrograman PHP dan MySql sebagai basis data.

5. Dilakukan pengujian sebagai penentu rute optimal dalam pengambilan sampah.

\subsection{Gambaran Teknologi Yang Akan} Dikembangkan

Gambaran teknologi yang akan dikembangkan ditunjukkan pada gambar 1 berikut.

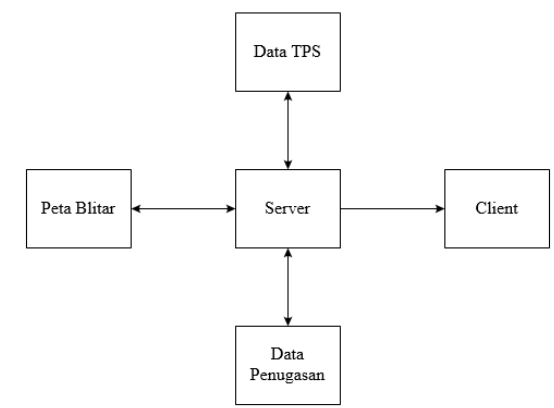

Gambar 1. Gambaran Teknologi yang akan dikembangkan 
Gambar 1 merupakan gambaran teknologi yang akan dikembangkan dimana terdapat peta wilayah Blitar yang akan diolah didalam WebGismenggunakan Bahasa Javascript. Terdapat data TPS dan data penugasan pengambilan sampah yang disimpan didalam database. Dan dikemudian diolah oleh webserver. Untuk Bahasa yang digunakan untuk berkomunikasi antara databaseserver dan webserver adalah bahasa pemrograman PHP. Kemudian client dalam hal ini adalah program untuk pengguna bisa dapat mengakses data tersebut menggunakan komunikasi dengan bahasa PHP.

\subsection{Blok Diagram Sistem}

Blok diagram merupakan representasi dari sebuah fungsi yang terdapat dalam sebuah system. Terdapat input, proses dan output. Pada input terdapat data spasial Blitar dan data atribut Blitar, data penugasan pengambilan sampah dan data lokasi TPS. Pada proses terdapat analisis data tabular dan analisis data spasial. Pda output terdapat peta, informasi rute penugasan pengambilan sampah dan infromasi titik lokasi TPS.

Pada kerja system informasi geografis di tunjukkan pada gambar 2 berikut.

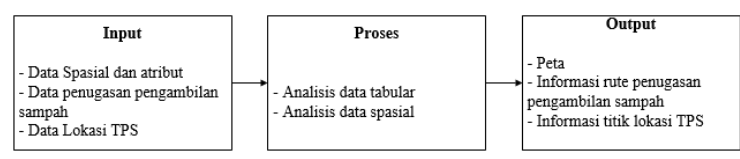

Gambar 2 Blok Diagram Sistem

\subsection{Flowchart Sistem}

Flowchart merupakan proses berjalan nya system seperti pada gambar 3 berikut.

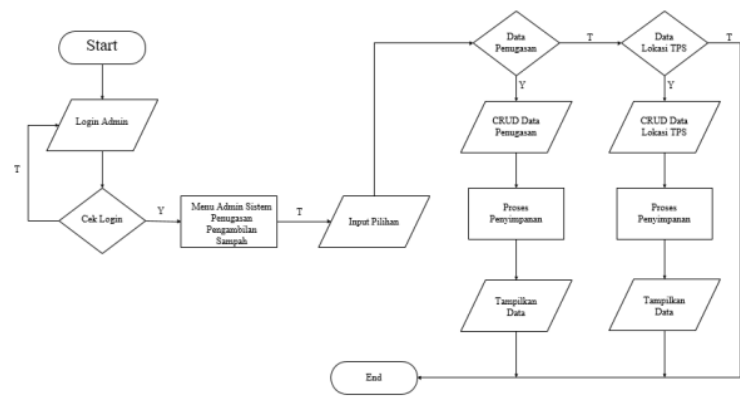

Gambar 3 Flowchart Sistem

Pertama masuk sebagai admin dengan menginputkan username dan password. Selanjutnya akan masuk pada menu utama system penugasan pengambilan sampah. Setelah itu akan ada menu inputan penugasan pengambilan sampah dan data lokasi tps.

Pada menu rute penugasan pengambilan sampah admin dapat membuat, melihat update dan menghapus data rute pengambilan sampah oleh Dinas Lingkungan Hidup (DLH). Selanjutnya akan masuk pada proses penyimpanan. Pada menu data lokasi
TPS admin juga dapat membuat, melihat, update dan menghapus data lokasi TPS.

\section{HASIL DAN PEMBAHASAN}

\subsection{Analisa Sistem}

Untuk mendapatkan rute pengambilan sampah dengan rute optimal dilakukan dengan tahap membuat Tabel Titik Koordinat.

a. Driver 1

Driver 1 mendapatkan tugas dalam pengambilan sampah di 2 TPS, yaitu TPS Pasar Desa Semen dan TPS Pasar Babadan. Dengan jumlah kendaraan 1 yang mempunyai kapasitas $22 \mathrm{~m}^{3} /$ hari.

Tabel 1.Struktur Tabel Titik Lokasi Driver 1

\begin{tabular}{|c|l|c|c|}
\hline \multirow{2}{*}{ No. } & \multicolumn{2}{|c|}{ Nama TPS } & \multicolumn{2}{|c|}{ Titik Korrdinat } \\
\cline { 3 - 4 } & TPS Pasar & Latitude & Longitude \\
\hline 2. & $\begin{array}{l}\text { Babadan } \\
\text { TPS Pasar Desa } \\
\text { Semen }\end{array}$ & -8.0625103 & 112.3091554 \\
\hline
\end{tabular}

b. Driver 2

Driver 1 mendapatkan tugas dalam pengambilan sampah di 3 TPS, yaitu TPS Majekan, TPS Kenogo dan TPS Pandean. Dengan jumlah kendaraan 1 yang mempunyai kapasitas $6 \mathrm{~m}^{3} /$ hari.

Tabel 2. Struktur Tabel Titik Lokasi Driver 2

\begin{tabular}{|c|l|l|l|}
\hline \multirow{2}{*}{ No. } & \multirow{2}{*}{ Nama TPS } & \multicolumn{2}{|c|}{ Titik Korrdinat } \\
\cline { 3 - 4 } & & Latitude & Longitude \\
\hline 1. & TPS Majekan & -8.0746793 & 112.3119776 \\
\hline 2. & TPS Kenogo & -8.0902349 & 112.2966999 \\
\hline 3. & TPS Pandean & -8.0952349 & 112.3108665 \\
\hline
\end{tabular}

\section{c. Driver 3}

Titik dalam pengambilan sampah driver 3 ini adalah 10 TPS dengan jumlah kendaraan 1 yang mempunyai kapasitas $6 \mathrm{~m}^{3} /$ hari. 10 TPS tersebut yaitu TPS Wlingi, TPS Perum Kendalrejo, TPS 3R Darungan, TPS Pasar Wlingi, TPS RSUD Wlingi, TPS Pasar Talun, TPS Polres Talun, TPS Desa Ploso Selopuro, TPS Pasar Kesamben dan TPS Pasar Ngadri.

Tabel 3. Struktur Tabel Titik Lokasi Driver 3

\begin{tabular}{|c|l|c|c|}
\hline \multirow{2}{*}{ No. } & \multirow{2}{*}{ Nama TPS } & \multicolumn{2}{|c|}{ Titik Korrdinat } \\
\cline { 3 - 4 } & & Latitude & Longitude \\
\hline 1 & TPS Wlingi & -8.0221516 & 112.3147249 \\
\hline 2 & $\begin{array}{l}\text { TPS Perum } \\
\text { Kendalrejo }\end{array}$ & -8.0588889 & 112.2572503 \\
\hline 3 & TPS 3R Darungan & -8.0670805 & 112.3136035 \\
\hline 4 & TPS Pasar Wlingi & -8.076346 & 112.3072554 \\
\hline 5 & TPS RSUD Wlingi & -8.0830962 & 112.3130363 \\
\hline 6 & TPS Pasar Talun & -8.0891667 & 112.2897222 \\
\hline 7 & TPS Polres Talun & -8.0894904 & 112.270194 \\
\hline 8 & $\begin{array}{l}\text { TPS Desa Ploso } \\
\text { Selopuro }\end{array}$ & -8.1466451 & 112.3045624 \\
\hline 9 & $\begin{array}{l}\text { TPS Pasar } \\
\text { Kesamben }\end{array}$ & -8.1472368 & 112.3642357 \\
\hline 10 & TPS Pasar Ngadri & -8.178846 & 112.3425332 \\
\hline
\end{tabular}




\section{d. Driver 4}

Titik dalam pengambilan sampah driver 4 ini adalah 12 TPS dengan jumlah kendaraan 1 yang mempunyai kapasitas $8 \mathrm{~m}^{3} /$ hari. 12 TPS tersebut yaitu TPS Gembong Cangkring, TPS SMP 1 Ponggok, TPS Srengat, TPS Pasar Nglegok, TPS Karangtaruna Nglegok, TPS Pasar Slorok, TPS Gaprang, TPS Kanigoro Lapangan, TPS Puskesmas Sutojayan, TPS RSU Aulia, TPS Pasar Lodoyo dan TPS Klinik Simahusada.

Tabel 4. Struktur Tabel Titik Lokasi Driver 4

\begin{tabular}{|c|l|c|c|}
\hline \multirow{2}{*}{ No. } & \multicolumn{2}{|c|}{ Nama TPS } & \multicolumn{2}{|c|}{ Titik Korrdinat } \\
\cline { 3 - 4 } & & Latitude & Longitude \\
\hline 1 & $\begin{array}{l}\text { TPS Gembong } \\
\text { Cangkring }\end{array}$ & -7.9974571 & 112.0914221 \\
\hline 2 & $\begin{array}{l}\text { TPS SMP } 1 \\
\text { Ponggok }\end{array}$ & -8.0228526 & 112.1120496 \\
\hline 3 & TPS Srengat & -8.079321 & 112.0375294 \\
\hline 4 & TPS Pasar Nglegok & -8.0346793 & 112.2011443 \\
\hline 5 & $\begin{array}{l}\text { TPS Karangtaruna } \\
\text { Nglegok }\end{array}$ & -8.0421793 & 112.2122554 \\
\hline 6 & TPS Pasar Slorok & -8.0394444 & 112.2453059 \\
\hline 7 & TPS Gaprang & -8.1202778 & 112.1930837 \\
\hline 8 & $\begin{array}{l}\text { TPS Kanigoro } \\
\text { Lapangan }\end{array}$ & -8.1338889 & 112.2191948 \\
\hline 9 & $\begin{array}{l}\text { TPS Puskesmas } \\
\text { Sutojayan }\end{array}$ & -8.1545746 & 112.215315 \\
\hline 10 & TPS RSU Aulia & -8.1604624 & 112.2153843 \\
\hline 11 & TPS Pasar Lodoyo & -8.1703292 & 112.2134894 \\
\hline 12 & $\begin{array}{l}\text { TPS Klinik } \\
\text { Simahusada }\end{array}$ & -8.1959796 & 112.1007709 \\
\hline
\end{tabular}

\section{e. Driver 5}

Titik dalam pengambilan sampah driver 5 ini adalah 10TPS dengan jumlah kendaraan 1 yang mempunyai kapasitas $6 \mathrm{~m}^{3} /$ hari. 10 TPS tersebut yaitu TPS Satreyan, TPS Tawangsari, TPS Pendopo Blitar, TPS Pasar Banggle, TPS Minggir Sari, TPS 3R Karangsono, TPS Kantor Bupati, TPS DPRD, TPS SMP 1 Talun, dan TPS Desa Jatitengah.

Tabel 5. Struktur Tabel Titik Lokasi Driver 5

\begin{tabular}{|c|l|c|c|}
\hline \multirow{2}{*}{ No. } & \multirow{2}{*}{ Nama TPS } & \multicolumn{2}{|c|}{ Titik Korrdinat } \\
\cline { 3 - 4 } & & Latitude & Longitude \\
\hline 1 & TPS Satreyan & -8.005803 & 112.3514514 \\
\hline 2 & TPS Tawangsari & -8.0557862 & 112.2070694 \\
\hline 3 & $\begin{array}{l}\text { TPS Pendopo } \\
\text { Blitar }\end{array}$ & -8.0964986 & 112.1634917 \\
\hline 4 & TPS Pasar Banggle & -8.1233252 & 112.1778167 \\
\hline 5 & TPS Minggir Sari & -8.1380084 & 112.1632877 \\
\hline 6 & $\begin{array}{l}\text { TPS 3R } \\
\text { Karangsono }\end{array}$ & -8.1261111 & 112.203917 \\
\hline 7 & TPS Kantor Bupati & -8.1299326 & 112.2112381 \\
\hline 8 & TPS DPRD & -8.126585 & 112.2186631 \\
\hline 9 & TPS SMP 1 Talun & -8.1127594 & 112.2717058 \\
\hline 10 & $\begin{array}{l}\text { TPS Desa } \\
\text { Jatitengah }\end{array}$ & -8.1379292 & 112.2910273 \\
\hline
\end{tabular}

\section{f. Driver 6}

Titik dalam pengambilan sampah driver 6 ini adalah 8 TPS Dengan jumlah kendaraan 1 yang mempunyai kapasitas $12 \mathrm{~m}^{3} /$ hari. 10 TPS tersebut yaitu TPS Desa Gandusari, TPS Jajar, TPS RS Anisa Talun, TPS Pasar Garum, TPS Desa Pojok, TPS Plosoarang, TPS Kampung Coklat, TPS Kelurahan Kademangan.

Tabel 6. Struktur Tabel Titik Lokasi Driver 6

\begin{tabular}{|c|l|c|c|}
\hline \multirow{2}{*}{ No. } & \multirow{2}{*}{ Nama TPS } & \multicolumn{2}{|c|}{ Titik Korrdinat } \\
\cline { 3 - 4 } & & Latitude & Longitude \\
\hline 1 & $\begin{array}{l}\text { TPS Desa } \\
\text { Gandusari }\end{array}$ & -7.9980431 & 112.274578 \\
\hline 2 & TPS Jajar & -8.0668487 & 112.2860208 \\
\hline 3 & $\begin{array}{l}\text { TPS RS Anisa } \\
\text { Talun }\end{array}$ & -8.083195 & 112.2994637 \\
\hline 4 & TPS Pasar Garum & -8.0727778 & 112.2144726 \\
\hline 5 & TPS Desa Pojok & -8.0748496 & 112.1871984 \\
\hline 6 & TPS Plosoarang & -8.1360682 & 112.1366999 \\
\hline 7 & $\begin{array}{l}\text { TPS Kampung } \\
\text { Coklat }\end{array}$ & -8.1567634 & 112.1696013 \\
\hline 8 & $\begin{array}{l}\text { TPS Kelurahan } \\
\text { Kademangan }\end{array}$ & -8.179081 & 112.0713719 \\
\hline
\end{tabular}

\section{g. Driver 7}

Titik dalam pengambilan sampah driver 7 ini adalah 1 TPS Dengan jumlah kendaraan 1 yang mempunyai kapasitas $8 \mathrm{~m}^{3} /$ hari. 10 TPS Tlogo.

Tabel 7. Struktur Tabel Titik Lokasi Driver 7

\begin{tabular}{|c|l|c|c|}
\hline \multirow{2}{*}{ No. } & \multirow{2}{*}{ Nama TPS } & \multicolumn{2}{|c|}{ Titik Korrdinat } \\
\cline { 3 - 4 } & & Latitude & Longitude \\
\hline 1 & \multirow{2}{*}{ TPS Tlogo } & - & \multirow{2}{*}{112.1905972} \\
\hline
\end{tabular}

\subsection{Hasil}

Hasil tampilan halaman home ditujunkkan pada gambar 4 berikut.

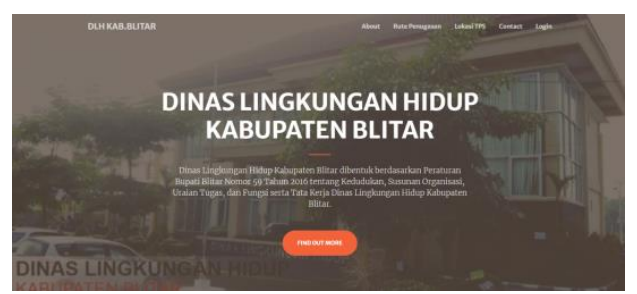

Gambar 4 Halaman Home

Hasil tampilan halaman titik lokasi pemetaan TPS dapat ditunjukkan pada gambar 5 berikut.

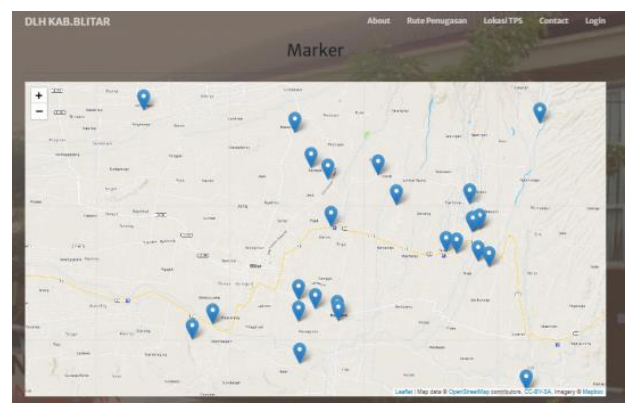

Gambar 5 Tampilan Lokasi TPS 
Hasil tampilan halaman rute penugasan pengambilan sampah dapat ditunjukkan pada gambar 6 berikut..

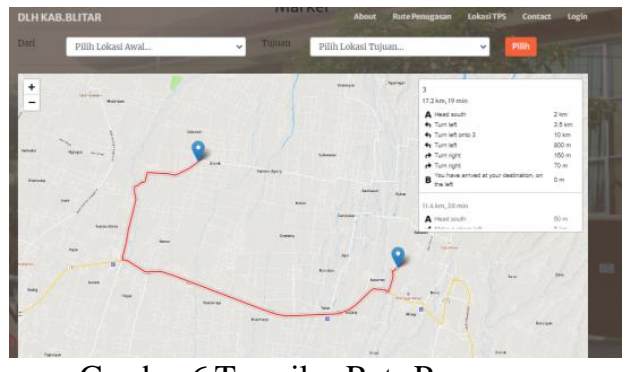

Gambar 6 Tampilan Rute Penugasan

Hasil tampilan halaman dashboard admin dapat ditujukkan pada gambar 7 berikut.

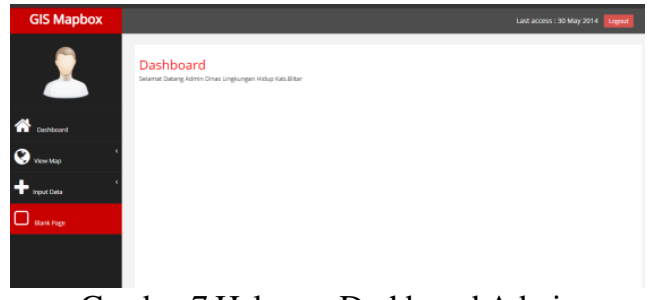

Gambar 7 Halaman Dashboard Admin

Hasil tampilan halaman data lokasi TPS dapat ditujukkan pada gambar 8 berikut.
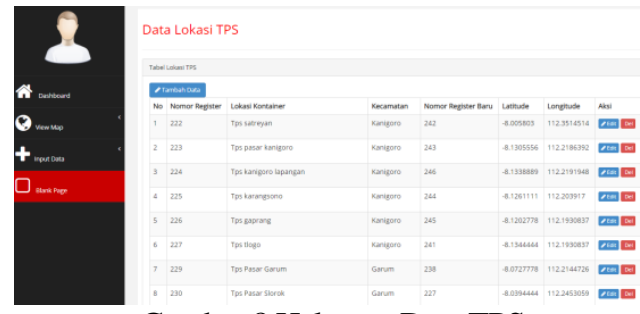

Gambar 8 Halaman Data TPS

Hasil tampilan halaman data penugasan pengambilan sampah dapat ditunjukkan pada gambar 9 berikut.
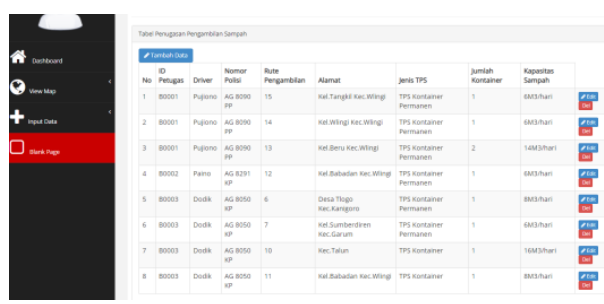

Gambar 9 Halaman Data Penugasan

\subsection{Pengujian Blackbox}

Pengujian ini dilakukan untuk mengetahui apakah seluruh fungsi dapat berjalan dengan baik sesuai dengan desain yang telah dibuat.
Tabel 8. Pengujian Blackbox

\begin{tabular}{|c|c|c|}
\hline $\begin{array}{l}\text { Nama } \\
\text { Fungsi }\end{array}$ & Status & Keterangan \\
\hline $\begin{array}{l}\text { Tampil } \\
\text { Peta }\end{array}$ & $\mathrm{OK}$ & $\begin{array}{l}\text { Peta dapat di-load setelah ada } \\
\text { peng-input-an data peta dari } \\
\text { admin, membutuhkan internet } \\
\text { untuk me-load peta dari } \\
\text { openstreetmaps. }\end{array}$ \\
\hline $\begin{array}{l}\text { Tampil } \\
\text { Peta } \\
\text { Aktif }\end{array}$ & $\mathrm{OK}$ & $\begin{array}{l}\text { Peta yang aktif dapat tampil } \\
\text { dengan baik }\end{array}$ \\
\hline $\begin{array}{l}\text { Input } \\
\text { data rute }\end{array}$ & $\mathrm{OK}$ & $\begin{array}{l}\text { Input data rute berjalan dengan } \\
\text { baik }\end{array}$ \\
\hline $\begin{array}{l}\text { Edit data } \\
\text { rute }\end{array}$ & $\mathrm{OK}$ & $\begin{array}{l}\text { Edit datarute berjalan dengan } \\
\text { baik }\end{array}$ \\
\hline $\begin{array}{l}\text { Hapus } \\
\text { data rute }\end{array}$ & $\mathrm{OK}$ & $\begin{array}{l}\text { Hapus data rute berjalan dengan } \\
\text { dengan baik }\end{array}$ \\
\hline $\begin{array}{l}\text { Tampil } \\
\text { data rute }\end{array}$ & OK & $\begin{array}{l}\text { Tampil data ruteberjalan dengan } \\
\text { baik }\end{array}$ \\
\hline $\begin{array}{l}\text { Tampil } \\
\text { data TPS }\end{array}$ & $\mathrm{OK}$ & $\begin{array}{l}\text { Tampil data TPS berjalan } \\
\text { dengan baik, seluruh data dapat } \\
\text { tampil di dalam tabel yang } \\
\text { dibuat }\end{array}$ \\
\hline $\begin{array}{l}\text { Input } \\
\text { data TPS }\end{array}$ & $\mathrm{OK}$ & $\begin{array}{l}\text { Input data TPS dapat berjalan } \\
\text { dengan baik, terdapat validation, } \\
\text { dan alert yang dapat berjalan } \\
\text { dengan baik }\end{array}$ \\
\hline $\begin{array}{l}\text { Hapus } \\
\text { data TPS }\end{array}$ & OK & $\begin{array}{l}\text { Hapus data TPS dapat berjalan } \\
\text { dengan baik, dan alert yang } \\
\text { dapat berjalan dengan baik }\end{array}$ \\
\hline
\end{tabular}

\subsection{Pengujian Fungsional}

Pengujian fungsional ini dilakukan untuk mengetahui apakah aplikasi yang telah dibuat dapat berjalan dengan baik. Pada tabel 9 dibawah ini merupakan hasil dari pengujian fungsi menggunakan desktop kompuer.

Tabel 9. Pengujian Fungsi Menggunakan Dekstop

\begin{tabular}{|c|l|c|c|c|}
\hline \multirow{4}{*}{$\begin{array}{c}\text { Hak } \\
\text { Akses }\end{array}$} & \multirow{2}{*}{ Fungsional } & \multicolumn{3}{|c|}{ Browser } \\
\cline { 3 - 5 } & Chrome & Edge & Opera \\
\hline \multirow{5}{*}{ User } & Home & OK & OK & OK \\
\cline { 2 - 5 } & Tampil Peta & OK & OK & OK \\
\cline { 2 - 5 } & Tampil Rute & OK & OK & OK \\
\cline { 2 - 5 } & Tampil Titik & OK & OK & OK \\
\hline \multirow{5}{*}{ Admi } & Tambah Rute & OK & OK & OK \\
\cline { 2 - 5 } & Edit Rute & OK & OK & OK \\
\cline { 2 - 5 } & Delete Rute & OK & OK & OK \\
\cline { 2 - 5 } & Cari Rute & OK & OK & OK \\
\cline { 2 - 5 } & Tambah TPS & OK & OK & OK \\
\cline { 2 - 5 } & Edit TPS & OK & OK & OK \\
\cline { 2 - 5 } & Delete TPS & OK & OK & OK \\
\cline { 2 - 5 } & Lihat TPS & OK & OK & OK \\
\hline
\end{tabular}

Fungsi pada browser (Chrome, Edge dan Opera) sudah berjalan $100 \%$ sesuai dengan kebutuhan aplikasi

\subsection{Pengujian Pengguna}

Pengujian pengguna dilakukan terhadap 10 responden yang terdiri dari masyarakat umum yang nantinya akan sering mengakses aplikasi ini. Pada 
tabel 10 berikut merupakan hasil dari pengujian pengguna.

Tabel 10. Pengujian Pengguna

\begin{tabular}{|c|c|c|c|c|}
\hline \multirow{2}{*}{ No. } & \multirow{2}{*}{ Pertanyaan } & \multicolumn{3}{|c|}{ Respon } \\
\hline & & Baik & Cukup & Kurang \\
\hline 1 & $\begin{array}{l}\text { Bagaimana menurut } \\
\text { Anda mengenai } \\
\text { Desain dari } \\
\text { WebsiteRute } \\
\text { Penugasan } \\
\text { Pengambilan Sampah } \\
\text { Kabupaten Blitar }\end{array}$ & 5 & 5 & - \\
\hline 2 & $\begin{array}{l}\text { Apakah penggunaan } \\
\text { aplikasi lebih mudah } \\
\text { digunakan? }\end{array}$ & 7 & 2 & 1 \\
\hline 3 & $\begin{array}{l}\text { Apakah semua menu } \\
\text { website berjalan } \\
\text { dengan baik? }\end{array}$ & 6 & 4 & - \\
\hline 4 & $\begin{array}{l}\text { Apakah informasi rute } \\
\text { penugasan dan lokasi } \\
\text { TPS dapat ditampilkan } \\
\text { ? }\end{array}$ & 8 & 2 & - \\
\hline 5 & $\begin{array}{l}\text { Apakah aplikasi dapat } \\
\text { membantu petugas } \\
\text { dalam melihat rute } \\
\text { penugasan } \\
\text { pengambilan sampah? }\end{array}$ & 8 & 1 & 1 \\
\hline
\end{tabular}

\section{KESIMPULAN DAN SARAN}

\subsection{Kesimpulan}

Berdasarkan beberapa pengujian yang telah dilakukan didapatkan beberapa kesimpulan :

1. Dapat mempermudah petugas Dinas Lingkungan Hidup Kabupaten Blitar dalam pengambilan sampah dengan rute optimal.

2. Dapat menampilkan titik wilayah pemetaan rute penugasan pengambilan sampah pada peta Kabupaten Blitar berbasis website.

3. Dapat mengetahui efisiensi waktu pengangkutan sampah yang dilakukan oleh petugas DInas Lingkungan Hidup (DLH) Kabupaten Blitar.

\subsection{Saran}

Berdasarkan penelitian yang telah dilakukan penulis memberikan saran untuk pengembangan aplikasi selanjutnya antara lain :

1. Kedepan dapat membuat web ini dalam bentuk mobile untuk menggunakan perangkat mobile menggunakan Android dengan bahasa pemrograman Java ataupun Kotlin.

2. Perlu dikembangkan kembali desain tampilan agar lebih menarik pengunjung.

\section{DAFTAR PUSTAKA}

[1] S.I. Utami, "Aplikasi Pencarian Rute Terpendek Menggunakan Algoritma Genetika," Jurnal Coding Sistem Komputer Universitas Tanjungpura, vol.02, no.2338-493, 2014.

[2] Fajar, S, 2010, Aplikasi Penginderaan Jauh dan GIS Untuk Penentuan Lokasi TPA Sampah di Kota Surabaya. SNATI Yogyakarta. ISSN.19075022

[3] Andy Mizwar, Putri Rachmalia K. "Aplikasi Sistem Informasi Geografis (SIG) Untuk Pemetaan Sebaran Tempat Pembuangan Sampah Ilegal di Kota Banjarbaru, Kalimantan Selatan.” Jurnal Teknik Lingkungan Kalimantan Selatan.2016

[4] Sarino, Nyimas Septi, Dewi Astuti., "Analisis Truk Pengangkut Sampah di Wilayah Seberang Ulu Kota Palembang." Jurnal Penelitian dan Kajian Bidang Teknik Sipil, 2017

[5] Isti Surjandari, Akhmad Hidayatno, Ade Supriatna. "Model DinamisPengelolaan Sampah Untuk Mengurangi Beban Penumpukan.”Jurnal Teknik Industri.2009

[6] Tumimomor. Mailany, "Sistem Informasi Geografis Pariwisata Kota Kupang," Jurnal Nasional Pendidikan Teknik Informatika (JANAPATI), vol.01, no.2, 2013.

[7] Tumimomor. Mailany, "Sistem Informasi Geografis Pariwisata Kota Kupang," Jurnal Nasional Pendidikan Teknik Informatika (JANAPATI), vol.01, no.2, 2013.

[8] Ibnu Wardana. M, "Rancang bangun Sistem Informasi Geografis Pemetaan Ruang Ujian Menggunakan Bootsrap dan Leaflet.js," Seminar Nasional Teknologi Informasi Komunikasi dan Industri, ISSN.2579-7271, 2017.

[9] Ibnu Wardana. M, "Rancang bangun Sistem Informasi Geografis Pemetaan Ruang Ujian Menggunakan Bootsrap dan Leaflet.js," Seminar Nasional Teknologi Informasi Komunikasi dan Industri, ISSN.2579-7271, 2017.

[10] B. Cahyono, "Perancangan Sistem Informasi Geografis Zona Nilai Tanah Berabsis Website Menggunakan Leaflet Javascript Library," Jurnal Teknik ITS, vol.5, no.2337-3539, 2016. 